\title{
Humic Substances With Mineral Fertilization on Nutrient Availability in Irrigated Soil
}

\author{
Rose Luiza Moraes Tavares ${ }^{1}$, Cleire Luciano de Oliveira ${ }^{1}$, Renato Lara de Assis ${ }^{2}$, \\ Silvio Vasconcelos de Paiva Filho ${ }^{1}$, Camila dos Santos Ferreira ${ }^{1} \&$ Paulo Fernandes Boldrin ${ }^{1}$ \\ ${ }^{1}$ School of Agronomy, Rio Verde University, Rio Verde, Brazil \\ 2 School of Agronomy, Federal Institute Goiano, Iporá, Brazil \\ Correspondence: Rose Luiza Moraes Tavares, School of Agronomy, Rio Verde University, Fazenda Fontes do \\ Saber, P.O. box 104, Rio Verde, GO, Zip Code 75901-970, Brazil. Tel: 55-(64)-3611-2214. E-mail: \\ roseluiza@unirv.edu.br
}

Received: June 30, 2021

Accepted: July 27, 2021

Online Published: August 15, 2021

doi:10.5539/jas.v13n9p104

URL: https://doi.org/10.5539/jas.v13n9p104

\begin{abstract}
This study aimed to evaluate the alternative use of humic substances (humic and fulvic acid) combined or not with mineral fertilization containing Nitrogen $(\mathrm{N})$, Phosphorus $(\mathrm{P})$ and Potassium $(\mathrm{K})$ in the process of nutrient retention in the soil. For this, an experiment was conducted in a greenhouse with PVC columns of $40 \mathrm{~cm}$ high and $5 \mathrm{~cm}$ in diameter, where they were filled with Oxisol sample, being half of the treatments fertilized with NPK and half without at. Humic substances were added at doses equivalent to $0,60,120$ and, $240 \mathrm{~L} \mathrm{ha}^{-1}$. After this, 10 irrigations were made with $32 \mathrm{~mm}$ rain simulation. After 30 days, soil samples were collected in the upper $(0-20 \mathrm{~cm})$ and lower $(20-40 \mathrm{~cm})$ layers of the columns. Soil samples were evaluated for $\mathrm{P}, \mathrm{K}, \mathrm{Ca}, \mathrm{Mg}$ content, $\mathrm{pH}$, and soil conductivity. The experiment was in a completely randomized design, with a factorial statistical scheme of $2 \times 2 \times 4$ with three replicates. The results showed that mineral fertilization complemented with the use of humic acid promoted a higher residual effect of $\mathrm{Ca}$ and $\mathrm{K}$ in the soil after 30 days. The fulvic acid, when used in a complementary way to mineral fertilization, promoted a higher amount of $\mathrm{P}$ in the soil. In the absence of mineral fertilization, the effect of humic substance use is low on the availability of nutrients in the soil.
\end{abstract}

Keywords: fertilizer, fulvic acid, humic acid

\section{Introduction}

Brazilian Cerrado soils are naturally low in available nutrients. To maintain high agricultural productivity, the addition of fertilizers is required alongside careful management to preserve soil longevity and water quality.

The main limitations in most Cerrado soils, especially Oxisols, are insufficient development of negative electric charges, high $\mathrm{P}$ adsorption, and low nutrient availability (Souza \& Lobato, 2004; M. A. Baldotto \& L. E. B. Baldotto, 2014; Silva \& Lana, 2015) mainly due to the intense weathering caused by high rainfall and temperatures in the region. These limitations can be addressed by increasing the organic matter content of the soil. The functional groups present in organic matter help to improve cation exchange capacity (CEC), increase nutrient availability, decrease the specific adsorption of $\mathrm{P}$, and reduce the toxicity of aluminum and other heavy metals (Rose et al., 2014; Guo, Liu, \& Wu, 2019).

The functional groups of soil organic matter consist of simple and complex organic molecules. Simple molecules, such as proteins or carbohydrates, have a high lability and short residence times in soil. Complex molecules, such as humic substances (HSs), have longer residence times and are capable of improving the chemical, physical and biological properties of the soil (M. A. Baldotto \& L. E. B. Baldotto, 2014). According to Qian et al. (2015), HSs can be an important reservoir of N, P, and K, while also improving the physical structure, aeration, and drainage of soil. The use of HSs to improve soil properties has long been an interest for the fertilizer industry which has developed products based on fulvic acid (FA) and humic acid (HA).

Other benefits of HSs includes improvements in soil aggregation and porosity (Tavares et al., 2019), increased CEC (Silva \& Lana, 2015), complexation of ions (Canellas et al., 2015), reduction of leaching (Guo et al., 2019; 
Rose et al., 2014), increased soil microbiota (Zhang et al., 2013), and increased efficiency of mineral fertilization (Karčauskienè et al., 2019).

There is skepticism regarding the effectiveness of HSs, despite their proven positive effects. Part of the reason for this is their variation in physical and chemical properties (Rose et al., 2014). They can be formed in a diversity of environmental conditions which makes them heterogeneous and their molecular structure difficult to define (M. A. Baldotto \& L. E. B. Baldotto, 2014). Furthermore, the recommended application rates of commercial products based on HSs are generally small in relation to the natural amount present in the soil, and consequently, the effects of HSs are substantially less predictable than those of inorganic fertilizers (Rose et al., 2014).

This study tested the effect of HSs (HAs and FAs) in various combinations with NPK fertilization on nutrient retention in soil. The aim was to identify the limitations and potential applications of commercial products based on HSs in Brazilian Cerrado soils. It was hypothesized that the addition of HSs in combination with NPK fertilization would promote greater nutrient retention in the soil.

\section{Method}

The experiment was conducted in an acclimatized greenhouse for 30 days (November to December) under natural light, $70 \%$ relative humidity, in a constant temperature range between 25 and $30{ }^{\circ} \mathrm{C}$. It was conducted in the city of Rio Verde, Goiás, Brazil (Koppen-Geiger classification = Aw) (Lopes Sobrinho et al., 2020).

The soil bulk density was mesured using a volumetric ring of $100 \mathrm{~cm}^{-3}$. Based on a density of $1.2 \mathrm{~g} \mathrm{~cm}^{3}$, it was calculated that each column contained approximately $0.9 \mathrm{~kg}$ of soil. The HSs (fulvic or humic acid) were added in doses equivalent to $0,60,120$, and $240 \mathrm{~L} \mathrm{ha}^{-1}$, which equated to $0,20,40$, and $80 \mu \mathrm{L} \mathrm{column}{ }^{-1}$, respectively. These were administered in solutions of $5.0 \mathrm{~mL} \mathrm{column}^{-1}$ due to the small quantity of HSs per dose.

The HS treatments used two commercial products: one with a greater amount of HA and the other with a greater amount of FA (Table 1). These treatments were applied in combination with the presence or absence of NPK fertilization.

Table 1. Chemical and physical analysis of commercial products containing humic and fulvic acid

\begin{tabular}{llll}
\hline Variable & Unit & Humic acid (HA) & Fulvic acid (FA) \\
\hline Carbon-Humic acid (HA) & $\%$ & 25.0 & 2.3 \\
Carbon-Fulvic acid (FA) & $\%$ & 5.0 & 26.0 \\
Density & $\mathrm{g} \mathrm{mL}^{-1}$ & 1.0 & 1.3 \\
$\mathrm{pH}$ & - & 3.4 & 2.9 \\
Organic carbon & $\%$ & 31.0 & 18.0 \\
Nitrogen & $\%$ & 3.2 & 1.5 \\
Dry mass & $\%$ & 2.4 & 1.3 \\
Electrical conductivity (EC) & $\mu \mathrm{S} \mathrm{cm}^{-1}$ & 7.3 & 6.5 \\
\hline
\end{tabular}

The experimental plots were arranged in a completely randomized design (DIC) in a $2 \times 2 \times 4$ factorial arrangement. Factors included the presence or absence of mineral fertilization, two types of HSs and four application doses. There were three repetitions which totaled 48 sampling units.

A Oxisoil soil of medium texture with $34 \%$ clay was used. It was collected in an area of native vegetation at a depth of $0-20 \mathrm{~cm}$, and its characteristics are represented in Table 2. The soil was air dried and sieved at $2.0 \mathrm{~mm}$ to maintain uniformity of porosity between treatments.

Table 2. Chemical and physical characteristics of a Oxisoil from native Brazilian Cerrado vegetation in Rio Verde/GO

\begin{tabular}{|c|c|c|c|c|c|c|c|c|c|c|c|c|}
\hline Depth & $\mathrm{pH}$ & CEC & SB & K & $\mathrm{Ca}$ & $\mathrm{Mg}$ & $\mathrm{P}$ & V & $\mathrm{OM}$ & Sand & Silt & Clay \\
\hline $\mathrm{cm}$ & - & ------ & ---- & $\mathrm{nol} \mathrm{dm}$ & ----- & --.- & $\mathrm{mg} \mathrm{dm}{ }^{-3}$ & & ------ & \%- & 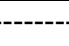 & -------- \\
\hline $0-20$ & 4.2 & 7.1 & 0.2 & 0.07 & 0.1 & 0.04 & 0.12 & 3.4 & 1.5 & 40.0 & 26.0 & 34.0 \\
\hline
\end{tabular}

Note. CEC: cation exchange capacity; SB: sum of bases $(\mathrm{Ca}+\mathrm{Mg}+\mathrm{K})$; V: base saturation; OM: organic matter. 
The soil samples (columns containing approximately $0.94 \mathrm{~kg}$ soil each) had their $\mathrm{pH}$ corrected with lime (Calcium Carbonate) using an amount equivalent to $4.0 \mathrm{t} \mathrm{ha}^{-1}\left(0.9 \mathrm{~g}\right.$ column $\left.{ }^{-1}\right)$. To calculate the liming, the base saturation method (Raij, 1997) was used to raise the value to $60 \%$, which is ideal for the development of crops such as corn. The soil was kept under incubation for 30 days at $70 \%$ water retention capacity (WRC), following the methodology of Ruiz, Ferreira, and Pereira (2003), where the WRC specific to Oxisoil tropical soil was estimated by determining the soil moisture equivalent (EU) using the equation $\mathrm{WRC}=0.081+0.888 \mathrm{EU}\left(\mathrm{R}^{2}=\right.$ 0.910), where WRC and EU are expressed in $\mathrm{kg} \mathrm{kg}^{-1}$.

Half of the samples were fertilized with NPK using concentrations equivalent to those needed for a local corn (Zea mays L.) productivity of 6-8 $\mathrm{tha}^{-1}$. were applied the equivalent of $100 \mathrm{~kg} \mathrm{ha}^{-1}$ of $\mathrm{P}_{2} \mathrm{O}_{5}$ in the form of simple superphosphate; $70 \mathrm{~kg} \mathrm{ha}^{-1}$ of $\mathrm{K}_{2} \mathrm{O}$ in the form of $\mathrm{KCl}$; and $120 \mathrm{~kg} \mathrm{ha}^{-1}$ of $\mathrm{N}$ in the form of urea. The columns were $40 \mathrm{~cm}$ high with a diameter of $5 \mathrm{~cm}$; made of PVC; and were open at both ends. At the base of each column, an cloth filters were attached to retain the soil.

Each column received 10 irrigations over 30 days, from 10/10/2018 to 11/12/2018. Irrigations were performed every 3-4 days. The initial amount of water represented a rainfall of $32 \mathrm{~mm}$, which is ideal for the start-up of grain crops. Subsequent additions of water were weighed and administered with the objective of maintaining the soil at field capacity. After 30 days, soil samples were collected from the columns in the upper $(0-20 \mathrm{~cm})$ and lower $(20-40 \mathrm{~cm})$ depths. These were air dried and sieved through a $2 \mathrm{~mm}$ mesh sieve (TFSA) prior to analysis of the $\mathrm{P}, \mathrm{K}, \mathrm{Ca}$, and $\mathrm{Mg}$ concentrations; and the $\mathrm{pH}$ and electrical conductivity in the soil as per the methodology of Teixeira, Donagemma, Fontana, and Teixeira (2017).

An analysis of variance (ANOVA) was performed to test the effect of different treatment combinations; and where significant effects were found, Tukey's test was applied at $5 \%$ probability to compare the means. A regression analysis was used to test the effect of HS doses. The data were analyzed using SAS software (Schlotzhaver \& Littell, 1997).

\section{Results and Discussion}

The ANOVA results showed that mineral fertilization had a significant positive effect $(\mathrm{p} \leq 0.05)$ on $\mathrm{P}, \mathrm{K}$, and $\mathrm{Ca}$ concentrations; and electrical conductivity (EC) in both the upper and lower layers of the columns (Table 3). The combined treatment of fertilization with HSs had a significant effect on Ca content in the upper soil layer ( $\mathrm{p} \leq$ 0.05). The use of HSs had a significant effect $(\mathrm{p} \leq 0.05)$ on Mg in both soil depths as did the dose of HSs $(\mathrm{p} \leq$ 0.05). The three-way interaction between fertilization, HSs, and the dose of HSs, had a significant effect ( $\mathrm{p} \leq$ 0.05 ) on $\mathrm{P}$ and $\mathrm{K}$ in the upper soil layer. 
Table 3. Analysis of variance with calculated Fc for nutrients retained in the upper $(0-20 \mathrm{~cm})$ and lower $(20-40$ $\mathrm{cm})$ soil layers of columns. Factors are defined below the table

\begin{tabular}{|c|c|c|c|c|c|c|c|}
\hline Variation factor & DF & $\mathrm{P}$ & $\mathrm{K}$ & $\mathrm{Ca}$ & $\mathrm{Mg}$ & $\mathrm{pH}$ & $\mathrm{EC}$ \\
\hline \multicolumn{8}{|l|}{$0-20 \mathrm{~cm}$} \\
\hline Fertilization & 1 & $123.37 * *$ & $15.50 * *$ & $18.43 * *$ & $1.20 \mathrm{~ns}$ & $1.52 \mathrm{~ns}$ & $69.88 * *$ \\
\hline Humic substances-HSs & 1 & $0.09 \mathrm{~ns}$ & $1.29 \mathrm{~ns}$ & $3.39 \mathrm{~ns}$ & $9.49 * *$ & $0.67 \mathrm{~ns}$ & $0.54 \mathrm{~ns}$ \\
\hline Dose HSs & 3 & $1.15 \mathrm{~ns}$ & $0.83 \mathrm{~ns}$ & $2.63 \mathrm{~ns}$ & $2.89 *$ & $0.22 \mathrm{~ns}$ & $1.94 \mathrm{~ns}$ \\
\hline Fertilization $\times$ HSs & 1 & $0.04 \mathrm{~ns}$ & $1.39 \mathrm{~ns}$ & $12.69 * *$ & $0.46 \mathrm{~ns}$ & $1.57 \mathrm{~ns}$ & $0.003 \mathrm{~ns}$ \\
\hline Fertilization $\times$ Dose HSs $\times$ Dose SHs & 3 & $1.44 \mathrm{~ns}$ & $0.48 \mathrm{~ns}$ & $1.32 \mathrm{~ns}$ & $1.18 \mathrm{~ns}$ & $0.69 \mathrm{~ns}$ & $2.27 \mathrm{~ns}$ \\
\hline HSs $\times$ Dose HSs & 3 & $3.53^{*}$ & $3.14 *$ & $0.50 \mathrm{~ns}$ & $1.11 \mathrm{~ns}$ & $0.87 \mathrm{~ns}$ & $1.58 \mathrm{~ns}$ \\
\hline Fertilization $\times$ HSs $\times$ Dose HSs $\times$ SHs $\times$ Dose SHs & 3 & $3.18 *$ & $4.06^{*}$ & $1.16 \mathrm{~ns}$ & $0.73 \mathrm{~ns}$ & $0.33 \mathrm{~ns}$ & $1.87 \mathrm{~ns}$ \\
\hline Error & 32 & - & - & - & - & - & - \\
\hline CV & - & 56.46 & 62.09 & 9.94 & 21.30 & 16.37 & 27.67 \\
\hline \multicolumn{8}{|l|}{$20-40 \mathrm{~cm}$} \\
\hline Fertilization & 1 & $33.02 * *$ & $40.49 * *$ & $9.50 *$ & $0.98 \mathrm{~ns}$ & $0.33 \mathrm{~ns}$ & $361.93 * *$ \\
\hline Humic substances-HSs & 1 & $0.02 \mathrm{~ns}$ & $0.55 \mathrm{~ns}$ & $1.27 \mathrm{~ns}$ & $7.10 *$ & $3.02 \mathrm{~ns}$ & $0.26 \mathrm{~ns}$ \\
\hline Dose HSs & 3 & $0.52 \mathrm{~ns}$ & $0.52 \mathrm{~ns}$ & $5.85^{*}$ & $4.90 *$ & $0.35 \mathrm{~ns}$ & $0.55 \mathrm{~ns}$ \\
\hline Fertilization $\times$ HSs & 1 & $0.06 \mathrm{~ns}$ & $0.17 \mathrm{~ns}$ & $0.62 \mathrm{~ns}$ & $1.19 \mathrm{~ns}$ & $0.71 \mathrm{~ns}$ & $1.58 \mathrm{~ns}$ \\
\hline Fertilization $\times$ Dose HSs $\times$ Dose SHs & 3 & $0.72 \mathrm{~ns}$ & $0.24 \mathrm{~ns}$ & $0.71 \mathrm{~ns}$ & $0.27 \mathrm{~ns}$ & $1.64 \mathrm{~ns}$ & $0.10 \mathrm{~ns}$ \\
\hline HSs $\times$ Dose HSs & 3 & $2.48 \mathrm{~ns}$ & $1.26 \mathrm{~ns}$ & $1.03 \mathrm{~ns}$ & $2.82 \mathrm{~ns}$ & $3.51 \mathrm{~ns}$ & $0.05 \mathrm{~ns}$ \\
\hline Fertilization $\times \mathrm{HSs} \times$ Dose $\mathrm{HSs} \times \mathrm{SHs} \times$ Dose $\mathrm{SHs}$ & 3 & $2.42 \mathrm{~ns}$ & $1.22 \mathrm{~ns}$ & $0.99 \mathrm{~ns}$ & $1.78 \mathrm{~ns}$ & $0.04 \mathrm{~ns}$ & $1.91 \mathrm{~ns}$ \\
\hline Error & 32 & - & - & - & - & - & - \\
\hline$C V$ & - & 46.86 & 41.94 & 7.74 & 20.34 & 15.89 & 19.00 \\
\hline
\end{tabular}

Note. Fertilization: presence or absence of mineral fertilization; Humic substances, HSs: use of HA or FA; Dose HSs: dose of HSs. DF: degree of freedom; ns: not significant; *,**: significance at 5 and $1 \%$ probability, respectively.

The Tukey's test confirmed that, regardless of treatment with HSs, mineral fertilization promoted higher concentrations of $\mathrm{P}, \mathrm{K}$, and $\mathrm{Ca}$, as well as a greater $\mathrm{EC}$, than treatments without mineral fertilization. EC increased significantly at both sample depths. $\mathrm{P}, \mathrm{K}$, and $\mathrm{Ca}$ only increased significantly in the lower soil layer (Table 4). Interestingly, even though $50 \mathrm{mg} \mathrm{kg}^{-1}$ of $\mathrm{P}$ was added to the soil via mineral fertilizer, the amount of $\mathrm{P}$ remaining in the soil after 30 days was $8.1 \mathrm{mg} \mathrm{kg}^{-1}\left(16.2 \mathrm{~kg} \mathrm{ha}^{-1}\right)$ in the lower layer of the column, which is too little to supply the needs of plants. According to Souza and Lobato (2004), the average P requirement for plants is $30 \mathrm{~kg}$ or $60-100 \mathrm{~kg}$ of $\mathrm{P}_{2} \mathrm{O}_{5}$.

Table 4. Mean values of $\mathrm{P}, \mathrm{K}, \mathrm{Ca}$, and electrical conductivity (EC) in the upper and lower soil layers after 10 irrigation events, with the presence or absence of NPK fertilization

\begin{tabular}{lllll}
\hline NPK Fertilization & $\mathrm{P}$ & $\mathrm{K}$ & $\mathrm{Ca}$ & $\mathrm{EC}$ \\
\hline & - & & & \\
$0-20 \mathrm{~cm}$ & 0.5 & 40.7 & 5.2 & $124.8 \mathrm{~b}$ \\
Absence & 9.7 & 85.0 & 5.9 & $249.8 \mathrm{a}$ \\
Presence & & & & \\
$20-40 \mathrm{~cm}$ & $0.5 \mathrm{~b}$ & $41.4 \mathrm{~b}$ & $5.8 \mathrm{~b}$ & $133.6 \mathrm{~b}$ \\
Absence & $8.1 \mathrm{a}$ & $93.2 \mathrm{a}$ & $6.2 \mathrm{a}$ & $425.2 \mathrm{a}$ \\
Presence & &
\end{tabular}

Means followed by identical letters in each depth do not differ by the Tukey test at $5 \%$ probability.

It is possible that the mixing of $\mathrm{P}$ fertilizer with the soil enabled the high adsorption and consequent reduction in the availability of this element for plants (Malavolta, 1981). Moreover, a study by Machado, Souza, Andrade, Lana, and Korndorfer (2011) observed that in medium-textured soils, a higher dose of P fertilizer resulted in higher P adsorption. Novais, Smyth, and Nunes (2007) reported that the retention of exogenous P occurs via its precipitation in solution with $\mathrm{Fe}^{3+}$ and $\mathrm{Al}^{3+}$ in an acidic environment, and with $\mathrm{Ca}^{2+}$ in an alkaline environment. This adsorption effect is significant in weathered tropical soils where $\mathrm{Fe}^{3+}$ and $\mathrm{Al}^{3+}$ hydroxides are present in larger quantities. To reduce adsorption, localized application of $\mathrm{P}$ fertilizer is used wherein a large part of the plant's root system meets the added $P$. 
The $\mathrm{Ca}^{2+}$ content in the lower soil layer after fertilization treatment was $6.2 \mathrm{mg} \mathrm{kg}^{-1}$, which was significantly higher than that in the treatment without fertilization $(p<0.05)$ (Table 4). This may be due to the addition of simple superphosphate which contains 18 to $20 \% \mathrm{Ca}$.

The combined effect of mineral fertilization with HSs caused a significant increase in $\mathrm{Ca}^{2+}$ concentrations in the upper soil layer. Furthermore, this effect was greater in the soil which received a treatment of HA as opposed to FA, with $\mathrm{Ca}^{2+}$ values of 6.36 and $5.50 \mathrm{mg} \mathrm{kg}^{-1}$, respectively (Figure 1). This is likely because Ca participates in binding the HA to clay mineral particles in the soil; forming complexes with Fe and Al. Silva and Lana (2015) also detected a higher $\mathrm{Ca}^{2+}$ content in soil after adding HA doses; with the highest dose increasing its concentration by $100 \%$. This result highlights the importance of using HSs in combination with mineral fertilization and never as a substitute when considering the dynamics of nutrients in the soil. HSs have a variable chemical matrix and may or may not aid in making certain elements available in the soil, whereas mineral sources generally release readily available elements into the soil.

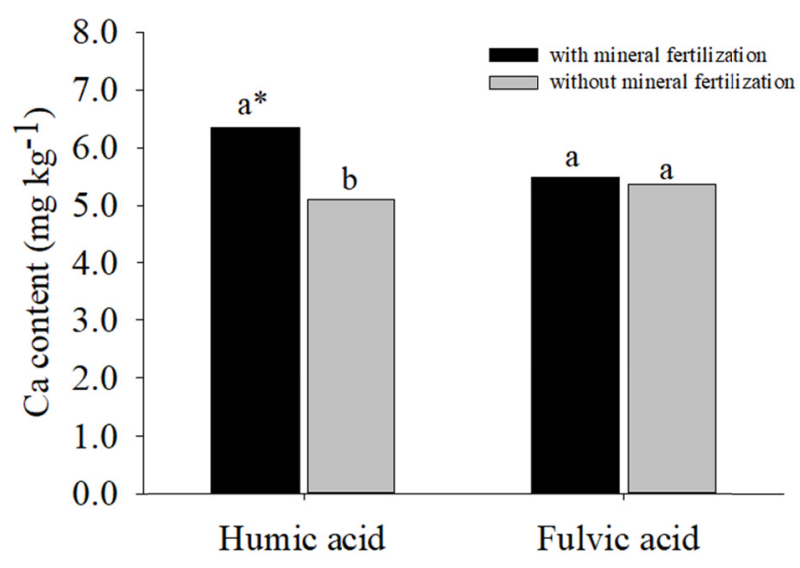

Figure 1. The exchangeable Ca content of the soil in the upper layer as a function of HA and FA application. Means followed by identical letters do not differ by the Tukey test at $5 \%$ probability. * Indicates a significant difference between the HSs regardless of mineral fertilizer application

The addition of HA promoted higher $\mathrm{Mg}^{2+}$ content in soil, with values of 1.1 and $0.9 \mathrm{mg} \mathrm{kg}^{-1}$ in the $0-20$ and $20-40 \mathrm{~cm}$ layers, respectively when compared to FA with 0.9 and $0.8 \mathrm{mg} \mathrm{kg}^{-1}$ in the $0-20$ and $20-40 \mathrm{~cm}$, respectively (Figure 2A). Silva and Lana (2015) also found that the addition of HA improved Mg availability. Their study tested the effect of treatments on $\mathrm{K}, \mathrm{Ca}$, and $\mathrm{Mg}$ availability, using humic and phosphoric acid with verdete rock as a mineral source.

Furthermore, as the dose of HSs increased, so did the Mg concentration in the soil. The relationship between available $\mathrm{Mg}$ and $\mathrm{HS}$ dose was linear in the lower layer, whereas in the upper layer, there was an increase in the $\mathrm{Mg}$ content until the dose reached $120 \mathrm{~L} \mathrm{ha}^{-1}$ (Figure 2B).

The higher values of available $\mathrm{Ca}$ and $\mathrm{Mg}$ associated with HA addition suggest that it is soil conditioner, whereas FA promotes improvements in soil aggregate stability (Tavares et al., 2019; Karčauskienè et al., 2019; Rose et al., 2014) and affects pore space and soil solution retention processes. In fact, Cihlar, Vojtová, Conte, Nasir, and Kucerík (2014) demonstrated that the addition of humic acid tripled the soil water retention potential.

The amount of available $\mathrm{P}$ and $\mathrm{K}$ in the lower soil layer after 30 days was influenced by the interaction of fertilization $\times$ HS $\times$ HS doses. The concentration of both elements increased with increasing application dose (Figure 3); however, this effect was only observed in the treatments with mineral fertilization. HSs increase the number of negative charges in the soil; and as a result, more cations can bind electrostatically to the solid phase, thereby reducing leaching (Silva \& Lana, 2015; M. A. Baldotto \& L. E. B. Baldotto, 2014).

According to Guo et al. (2019) and Canellas et al. (2015), HSs generate many stable ligands, promoting the formation of metal cation complexes. Their functional groups react rapidly with polyvalent cations on the surface of clay particles to form clay-metal-humus complexes (Piccolo, Pietramellara, \& Mbagwu, 1996; Rose et al., 2014). 
(A)
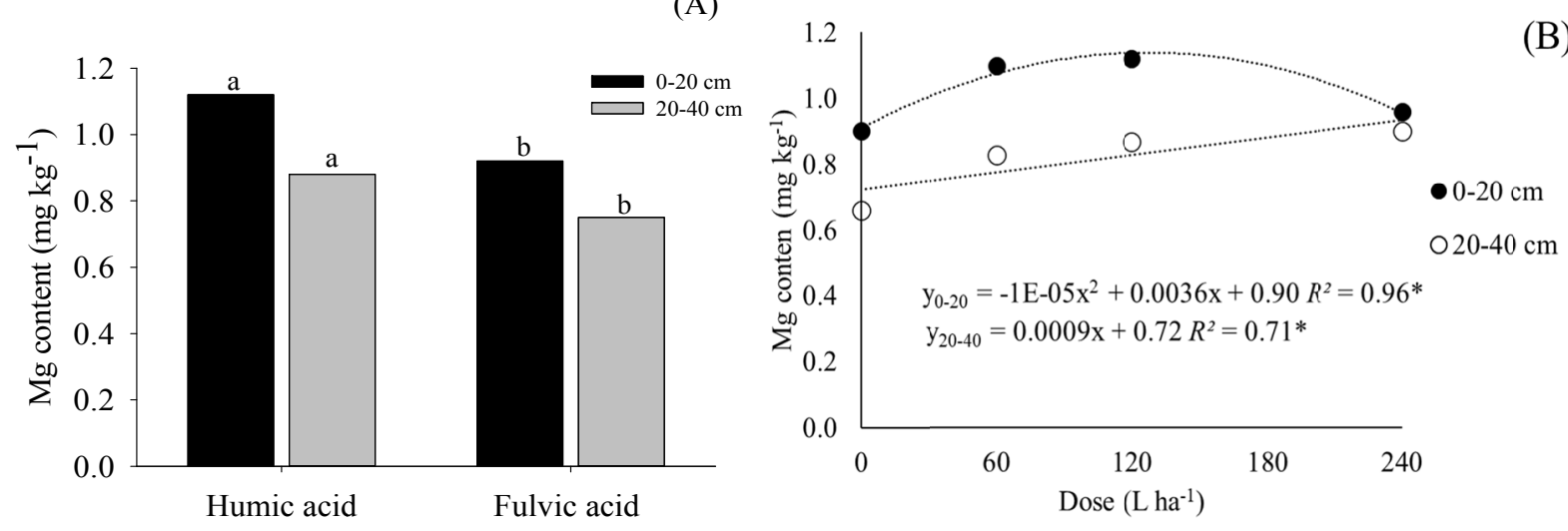

Figure 2. The effect of HS addition (A) and the application dose of HSs (B) on the Mg content of the soil in the upper and lower layers after 30 days. Means followed by the same letter did not differ significantly as confirmed by the Tukey test at $5 \%$ probability. Significant at $5 \%$

The addition of FA at a dose of $240 \mathrm{~L} \mathrm{ha}^{-1}$ increased the available $\mathrm{P}$ content in the soil from $3.33 \mathrm{mg} \mathrm{dm}^{-3}$ to $12.05 \mathrm{mg} \mathrm{dm}^{-3}$ (Figure 3A). Despite the low contribution of fulvic acid to P release, as $50 \mathrm{mg} \mathrm{kg}^{-1}$ of P was initially applied via mineral fertilization and only $14 \%$ was recovered with the addition of FA, some studies have shown that HSs have the potential to improve P availability in soils. Rose et al. (2014), and Guo et al. (2019) reported that the use of HSs can promote a reduction in the specific adsorption of $\mathrm{P}$, making the nutrient more readily available in the soil. Yang, Zhang, Cong, Wang, and Shi (2013) observed that as the applied dose of FA increased, there was a corresponding decrease in soil acidity, and an increase in CEC and the microbial population, which may have improved the conditions for $\mathrm{P}$ in the soil. In line with the results of this study, they concluded that the use of FA together with a mineral source is the best option for improving the physio-chemical conditions of the soil, and the availability of $\mathrm{P}$.

Increasing the dose of HA had a significant effect on the available K; however, the addition of FA did not (Figure 3C). Approximately $96 \%\left(114 \mathrm{mg} \mathrm{kg}^{-1}\right)$ of $\mathrm{K}$ was retained in the upper soil layer in the treatment which received mineral fertilization and the highest dose of HA.

The results of the treatments combining HA doses with mineral fertilization suggest that the addition of HA had a stronger impact on available $\mathrm{K}$ than mineral fertilization did. Prior to treatment with HA, the K concentration resulting from mineral fertilization was $35 \mathrm{mg} \mathrm{kg}^{-1}$. The addition of $\mathrm{HA}$ at a dose of $120 \mathrm{~L} \mathrm{ha}^{-1}$, for example, resulted in an increase 35 to $91 \mathrm{mg} \mathrm{kg}^{-1}$. Zhang et al. (2013) noticed a similar trend in Cambisolo, China; where soils fertilized with mineral compost and HA contained $\mathrm{K}$ at $320 \mathrm{mg} \mathrm{kg}^{-1}$, whereas soils fertilized without HA contained $\mathrm{K}$ at $250 \mathrm{mg} \mathrm{kg}^{-1}$. 


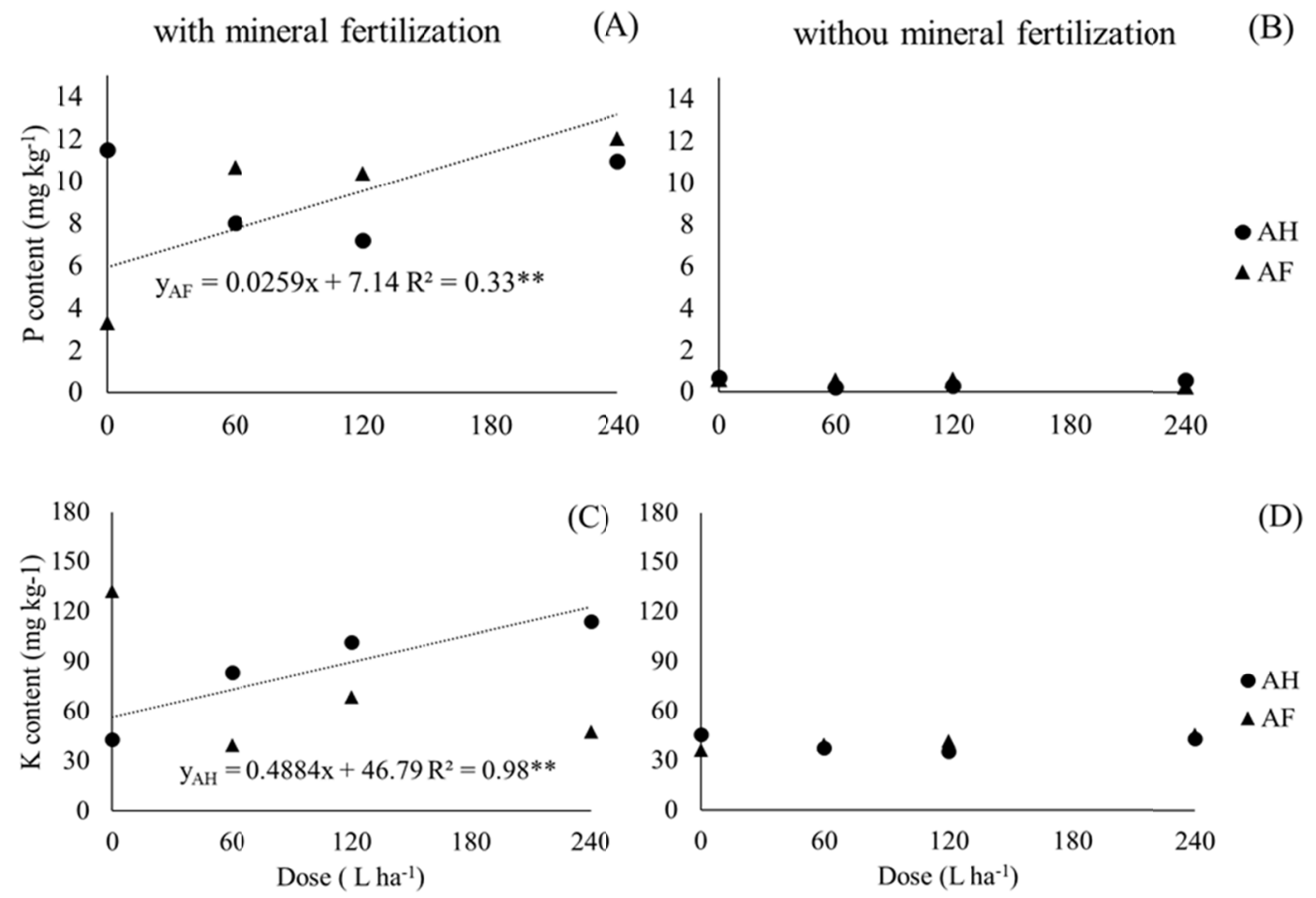

Figure 3. The Effect of adding HSs to soil, with and without mineral fertilization, on the content of P (A-B) and $\mathrm{K}(\mathrm{C}-\mathrm{D})$ in the upper soil layer after 30 days. ${ }^{* *}$ Indicates significance at $1 \%$ probability

\section{Conclusions}

The use of humic substances when used in combination with mineral fertilization increase the nutrient availability to plant. Specifically, the application of humic acid combined with mineral fertilization increased the levels of $\mathrm{Ca}$ and $\mathrm{K}$ in the $0-20 \mathrm{~cm}$ soil layer. The use of fulvic acid with mineral fertilization increased the available $\mathrm{P}$ in the soil at the same depth.

\section{Acknowledgements}

This work was supported by the University of Rio Verde (Master's degree in Crop Production) and was financed in part by the coordination for the improvement of Higher Education Personnel-Brazil (CAPES) "Finance Code $001 "$.

\section{References}

Baldotto, M. A., \& Baldotto, L. E. B. (2014). Humic acids. Ceres Journal, 61(Suppl.), 856-881. https://doi.org/ 10.1590/0034-737x201461000011

Canellas, L. P., Olivares, F. L., Aguiar, N. O., Jones, D. I., Nebbioso, A., Mazzei, P., \& Piccolo, A. (2015). Humic and fulvic acids as biostimulants in horticulture. Science Horticulturae, 196(30), 15-27. https://doi.org/ 10.1016/j.scienta.2015.09.013

Cihlar, Z., Vojtová, L., Conte, P., Nasir, S., \& Kucerík, J. (2014). Hydration and water holding properties of cross-linked lignite humic acid. Geoderma, 230-231, 151-160. https://doi.org/10.1016/j.geoderma.2014. 04.018

Guo, X. X., Liu, H. T., \& Wu, S. B. (2019). Humic substances developed during organic waste composting: form Zandoná action mechanisms, structural properties and agronomic functions. Science of the Total Environment, 662, 501-510. https://doi.org/10.1016/j.scitotenv.2019.01.137

Karčauskienė, D., Repšienė, R., Ambrazaitienė, D., Mockevičienė, I., Šiaudinis, G., \& Skuodienė, R. (2019). A complex assessment of mineral fertilizers with humic substances in an agroecosystem of acid soil. Zemdirbyste-Agriculture, 106(4), 307-314. https://doi.org/10.13080/z-a.2019.106.039

Lopes Sobrinho, O. P., Santos, L. N. S. dos, Santos, G. O., Cunha, F. N., Soares, F. A. L., \& Teixeira, M. B. (2020). Balanço hídrico climatológico mensal e classificação climática de Koppen e Thornthwaite para o 
município de Rio Verde, Goiás. Revista Brasileira de Climatologia, 27, 19-33. https://doi.org/10.5380/ abclima.v27i0.68692

Machado, V. J., Souza, C. H. E., Andrade, B. B., Lana, R. M. Q., \& Korndorfer, G. H. (2011). Curvas de disponibilidade de fósforo em solos com diferentes texturas após aplicação de doses crescentes de fosfato monoamônico. Bioscience Journal, 27(1), 70-76. Retrieved from http:/www.seer.ufu.br/index.php/ biosciencejournal/article/view/7389

Malavolta, E. (1981). Manual de química agrícola: Adubos e adubação. São Paulo: Agronômica Ceres.

Novais, R. F., Smyth, T. J., \& Nunes, F. N. (2007). Phosphorus. In R. F. Novais; V. Alvarez, N. F. Barros, R. L. F. Fontes, R. B. Cantarutti \& J. C. L. Neves (Eds.), Fertilidade do Solo. Viçosa: Sociedade Brasileira de Ciência do Solo.

Piccolo, A., Pietramellara, G., \& Mbagwu, J. S. C. (1996). Effect of coal derived humic substances on water retention and structural stability of Mediterranean soils. Soil and Use Management, 12(4), 209-213. https://doi.org/10.1111/j.1475-27431996.tb00545.x

Qian, S., Ding, W., Li, Y., Liu, G., Sun, I., \& Ding, Q. (2015). Characterization of humic acids derived from leonardite using solid-state MMR spectroscopy and effects of humic acids on growth and nutrient uptake of snap been. Chemical Speciation and Bioavailability, 27(4), 156-161. https://doi.org/10.1080/09542299. 2015.1118361

Raij, B. V., Cantarella, H., Quaggio, J. A., \& Furlani, A. M. C. (1997). Recomendações da adubação e calagem para o Estado de São Paulo. Boletim Técnico 100. Campinas, SP: Instituto Agronômico. Retrieved from https://www.iac.sp.gov.br/publicacoes/boletim100.php\#versao-eletronica

Rose, M. T., Patti, A. F., Little, K. R., Brown, A. L., Jackson, W. R., \& Cavagnaro, T. R. (2014). A meta-analysis and review of plant-growth response to humic substances: practical implications for agriculture. Advances in Agronomy, 124, 37-89. https://doi.org/10.1016/B978-0-12-800138-7.00002-4

Ruiz, H. A., Ferreira, G. B., \& Pereira, J. B. M. (2003). Field capacity of Oxisols and Quartzipsamments calculated from moisture equivalent determination. Revista Brasileira de Ciência do Solo, 27(2), 389-394. https://doi.org/10.1590/S0100-06832003000200019

Schlotzhaver, S. D., \& Littell, R. C. (1997). SAS: System for elementary statistical analysis (2nd ed.). Cary: SAS.

Silva, A. A., \& Lana, R. M. Q. (2015). Incubação de verdete com diferentes fontes de ácido para disponibilidade de potássio, cálcio, magnésio no solo. Holos, 5, 73-83. https://doi.org/ 10.15628/holos.2015.3210

Souza, D. M. G., \& Lobato, E. (2004). Cerrado: Correção do Solo e Adubação. Brasília: Embrapa Informação Tecnológica. Retrieved from https:/www.embrapa.br/busca-de-publicacoes/-/publicacao/555355/cerradocorrecao-do-solo-e-adubacao

Tavares, R. L. M., Assis, R. L., Ferreira, R. V., Menezes, J. F. S., Simon, G. A., Boldrin, P. F., \& Cantão, V. C. G. (2019). Long term application of pig manure on the chemical and physical properties of Brazilian Cerrado soil. Carbon Management, 10(6), 541-549. https://doi.org/10.1080/17583004.2019.1676095

Teixeira, P. C., Donagemma, G. K., Fontana, A., \& Teixeira, W. G. (2017). Manual de métodos de análise do solo (3rd ed.). Brasília, DF: Embrapa. Retrieved from https://www.embrapa.br/busca-de-publicacoes/-/ publicacao/1085209/manual-de-metodos-de-analise-de-solo

Yang, S., Zhang, Z., Cong, L., Wang, X., \& Shi, S. (2013). Effect of fulvic acid on the phosphorus availability in acid soil. Journal of Soil Science and Plant Nutrition, 13(3), 526-533. https://doi.org/10.4067/S0718-951 62013005000041

Zhang, L., Zhou, L., Zhao, Y. G., Zhai, Y., Wang, K., Alva, A. K., \& Paramasivam, S. (2013). Optimal combination of chemical compound fertilizer and humic acid to improve soil and leaf properties, yield and quality of apple (Malus domestica) in the loess plateau of China. Pakistan Journal of Botany, 45(4), 1315-1320. Retrieved from https://www.pakbs.org/pjbot/PDFs/45(4)/27.pdf

\section{Copyrights}

Copyright for this article is retained by the author(s), with first publication rights granted to the journal.

This is an open-access article distributed under the terms and conditions of the Creative Commons Attribution license (http://creativecommons.org/licenses/by/4.0/). 